\title{
Gerontologia (geragogika) specjalna - obszar koniecznych badań i refleksji pedagogiki specjalnej. Wybrane zagadnienia
}

\begin{abstract}
Iwona Chrzanowska, Gerontologia (geragogika) specjalna - obszar koniecznych badań i refleksji pedagogiki specjalnej. Wybrane zagadnienia [Special gerontology (geragogics) as the area of research and reflection for special pedagogics: Selected issues]. Interdyscyplinarne Konteksty Pedagogiki Specjalnej, nr 17, Poznań 2017. Pp. 117-31. Adam Mickiewicz University Press. ISSN 2300-391X

In the text, an attempt was made to analyse selected issues related to gerontology in the relationship to people with disabilities. The context of analyses is the tendency of social ageing tendencies, observed in Poland and in the world, especially in European countries. Selected areas of reflection are combined with the conviction that there is a need for research which would fill in the gap in the field of research carried out so far, focused on the issue of the broadly defined life situation of the people with disabilities in the senior years, which is in the scientific merit of Polish special needs education (pedagogics). There is a justified fear that these individuals are more likely to experience marginalisation and exclusion in many areas of life than people of similar age in the general population.
\end{abstract}

KEY WORDS: old age, person with disability, life situation 


\section{Wprowadzenie}

Problematyka niepełnosprawności i funkcjonowania osób z niepełnosprawnością stała się $\mathrm{w}$ ostatnich dekadach przedmiotem zainteresowań wielu dyscyplin naukowych nie tylko z obszaru nauk społecznych. Coraz częściej o osobach z niepełnosprawnością myśli się, projektując budynki, infrastrukturę miejską. Pojawiają się całe działy nauk technologicznych poświęconych projektowaniu sprzętu rehabilitacyjnego, medycznego, okazuje się bowiem, że zapotrzebowanie jest coraz większe, a prognozy, zwłaszcza demograficzne, wskazują na to, że będzie ono wciąż rosło.

Bez wątpienia istotny wpływ na rozwój zainteresowania problematyką niepełnosprawności i osoby z niepełnosprawnością miał również rozwój nauk humanistycznych i społecznych, upowszechnienie tendencji podnoszących prawa człowieka do rangi praw ogólnych jako podstawy budowania porządku społecznego. W konsekwencji pojawiły się hasła koniecznego przeciwdziałania wykluczeniu i marginalizacji człowieka $\mathrm{z}$ uwagi na jakikolwiek aspekt utrudnień rozwojowych - czy to związanych z indywidulanymi, społeczno-kulturowymi, gospodarczymi czy też geograficznymi uwarunkowaniami życia.

Prawa człowieka utożsamiane z prawami naturalnymi, przysługującymi wszystkim ludziom, oznaczały $\mathrm{w}$ istocie, że ludzi nie można różnicować $\mathrm{z}$ jakichkolwiek względów i w związku z tym przypisywać im różnych katalogów praw. Takie rozumienie stało się powszechne (przynajmniej w części świata) wcale nie tak dawno, bo dopiero $\mathrm{w}$ drugiej połowie $\mathrm{XX} \mathrm{w}$. Za formalny początek prymatu takiego sposobu myślenia uznać można przełom lat 40 . i 50. XX w., uchwalenie Powszechnej Deklaracji Praw Człowieka ${ }^{1}$. Od tego też momentu zaczęły pojawiać się również dokumenty międzynarodowe dedykowane poszczególnym grupom osób z niepełnosprawnością. W innych znalazły się zapisy, które we fragmen-

${ }^{1}$ Powszechna Deklaracja Praw Człowieka, http://www.unesco.pl/fileadmin/ user_upload/pdf/Powszechna_Deklaracja_Praw_Czlowika.pdf [dostęp: 12.02.2013]. 
tach odnosiły się do wybranych kategorii porządku społecznego, obszarów problemowych, sygnalizując brak równego traktowania, prawa osób z niepełnosprawnością².

2 Deklaracja Praw Osób z Upośledzeniem Umysłowym (Declaration on the Rights of Mentally Retarded Persons) - 1971 r. - podkreśla, że osoby niepełnosprawne intelektualnie mają te same prawa co inni ludzie oraz ustanawia specjalne prawa dla tych osób wynikające z ich potrzeb http://www.ohchr.org/EN/ProfessionalInterest /Pages/RightsOfMentallyRetardedPersons.aspx [dostęp: 31.05.2014]; Deklaracja Praw Osób Niepełnosprawnych (Declaration on the Rights of Disabled Persons) - 1975 r. potwierdzająca, że osoby z niepełnosprawnością mają takie same prawa obywatelskie I polityczne, jak inni ludzie http://www.ohchr.org/EN/ProfessionalInterest /Pages/RightsOfDisabledPersons.aspx [dostęp: 31.05.2014]; Rezolucja Zgromadzenia Ogólnego z 1976 r. ustanawiająca rok 1981 Międzynarodowym Rokiem Osób Niepełnosprawnych. W tym roku powstały międzynarodowe, regionalne i krajowe plany działań na rzecz osób z niepełnosprawnością, przewidujące działania na rzecz wyrównywania szans, leczenia, rehabilitacji i zapobiegania niepełnosprawności; Światowy Program Działań na rzecz Osób Niepełnosprawnych (World Programme of Action Concerning Disabled Persons), przyjęty na mocy rezolucji Zgromadzenia Ogólnego ONZ 3 grudnia 1982 r. http://www.who.int/disabilities/policies/standard_ rules/en/ [dostęp: 31.05.2014]; Zasady Tallińskie (Tallin Guidelines for Action on Human Resources Development in the Field of Disability), przyjęte w 1989 r., dotyczące edukacji i zatrudniania osób z niepełnosprawnością przez instytucje rządowe oraz na wszystkich poziomach władzy publicznej w celu wyrównywania szans osób z niepełnosprawnością http://www.un.org/documents/ga/res/44/a44r070.htm [dostęp: 31.05.2014]; Zasady Ochrony Osób Cierpiących na Choroby Psychiczne oraz Poprawy Opieki Zdrowotnej w tym Zakresie (Principles for the Protection of Persons with Mental Illness and for the Improvement of Mental Health Care), przyjęte w 1991 r. jako jeden z dokumentów końcowych Dekady Osób Niepełnosprawnych, ogłoszonej w latach 1983-1992 przez Zgromadzenie Ogólne ONZ. Dokument zawiera 25 głównych zasad, które określają prawa osób z niepełnosprawnością intelektualną http:/ / www.un.org/do cuments/ga/res/46/a46r119.htm [dostęp: 31.05.2014]; Standardowe Zasady Wyrównywania Szans Osób Niepełnosprawnych (The Standard Rules on the Equalization of Opportunities for Persons with Disabilities), przyjęte w 1993 r. przez Zgromadzenie Ogólne ONZ. Dokument określa modelowe kierunki rozwiązań dotyczących osób z niepełnosprawnością, stanowi podstawę tworzenia polityki i programów dotyczących osób z niepełnosprawnością. http://www.un.org/documents/ga/res/48/a48 r096.htm [dostęp: 31.05.2014]; Konwencja Praw Osób Niepełnosprawnych, przyjęta przez Zgromadzenie Ogólne ONZ w 2006 r. celem kodyfikacji praw osób z niepełnosprawnością, http://www.mpips.gov.pl/spoleczne-prawa-czlowieka/konwencja- 
Nie bez znaczenia dla rozwoju myśli i badań naukowych odnoszących się do problematyki równego traktowania, wykluczenia i marginalizacji osób czy grup społecznych miała w Polsce bez wątpienia dominująca, do niemal lat 90 . XX w. doktryna społeczno-polityczna. Lata opóźnienia, będące wynikiem przeszłego ustroju społecznego, wciąż są obciążeniem dla wielu dyscyplin naukowych w obszaru nauk społecznych i humanistycznych. W odniesieniu do problematyki pedagogiki specjalnej najlepiej ilustrują to przykłady opóźnień w ratyfikacji przyjmowanych przez ONZ czy UE deklaracji, rezolucji, dyrektyw dotyczących zagadnień: praw człowieka, równego traktowania czy niepełnosprawności. Dla przykładu: Europejska Karta Społeczna, uchwalona w Turynie w 1961 r., została ratyfikowana przez Polskę w 1997 r.; Karta Praw Podstawowych UE przyjęta w Nicei w 2000 r. i Traktat Lizboński z 2007 r., które weszły w życie w 2009 r., zostały przez Polskę przyjęte z ograniczeniami, a Konwencja Praw Osób Niepełnosprawnych, przyjęta prze ONZ w 2006 r., podpisana przez Polskę w 2007 r., została ratyfikowana (wprowadzona do polskiego porządku prawnego) pod koniec 2012 r. Ratyfikowanie aktów prawnych z opóźnieniem wynika z konieczności dostosowania wewnętrznego prawa danego państwa do postanowień międzynarodowych. $W$ tym jednak przypadku nieodparcie rodzi się refleksja, że prace nad owym dostosowaniem uwarunkowane są determinacją ustawodawcy, która w pewnym sensie wynika z nadanej problematyce rangi społecznej. Innym problemem, już nie tyle natury ustawodawczej, co społecznej, jest gotowość przyjęcia, zaakceptowania postulowanych rozwiązań3. Na tle innych państw UE Polska postrzegana jest jako kraj o konserwatywnych poglądach. Akceptacja odmienności, zróżnicowania wynikającego z niepełnosprawności, wyznania, orientacji seksualnej jest niejednokrotnie poważnym problemem. Nawet istniejące rozwią-

o-prawach-osob-niepelnosprawnych/ratyfikacja-konwencji-o-prawach-osob-niepelno sprawnych-przez-polske/ [dostęp: 1.06.2014].

3 Polska jest np. współcześnie postrzegana jako jeden $\mathrm{z}$ „najczystszych” etnicznie krajów UE. Trudno jest zatem forsować modele koegzystencji społeczeństwa wielokulturowego. 
zania formalno-prawne nie przesądzają w tym przypadku o możliwości pojawienia się określonych działań dyskryminujących.

Mimo wskazanych uwarunkowań, nie ma wątpliwości, że koniec XX i początek XXI w. stał się okresem wieloobszarowych badań nad zagadnieniami równości, przeciwdziałania wykluczeniu czy marginalizacji i w tych kontekstach zjawiska niepełnosprawności. Bazując na tym dorobku, warto zastanowić się nad polami przyszłych analiz naukowych w ramach pedagogiki specjalnej, ale również studiów interdyscyplinarnych.

\section{Starość osób z niepełnosprawnością}

Niemal nieobecnym problemem badawczym polskiej pedagogiki specjalnej jest starość $\mathrm{z}$ niepełnosprawnością. Tak w przypadku osób z niepełnosprawnością od urodzenia, wczesnego dzieciństwa, jak i nabytą. W kontekście wskaźników, obserwowanego zwłaszcza w Europie, wzrostu populacji osób starszych, bez kategoryzacji na osoby sprawne i z niepełnosprawnością, konieczne wydaje się również zintensyfikowanie współpracy subdyscyplin pedagogiki, zwłaszcza pedagogiki specjalnej, pedagogiki społecznej, pedagogiki osób starszych i starzejących się (geragogiki) w obszarze badań naukowych, ale również działań praktycznych, budowania systemowych działań na rzecz osób starszych. Przemawia za tym fakt, że okres starości, to czas, w którym pojawiać się będzie coraz więcej problemów zdrowotnych, przekładających się na obniżenie sprawności czy utratę sprawności. Warto byłoby jednak zadbać o to, by w możliwie najmniejszym stopniu skutkowało to obniżeniem się jakości życia człowieka.

Od dłuższego już czasu działania takie (subdyscyplinarne studia nad problematyką) są podejmowane w przypadku dzieci i młodzieży. Problematyka integracji edukacyjnej, w tym w ostatnich latach szczególnie edukacji włączającej, skłoniła badaczy zagadnienia, tak w przypadku pedagogiki specjalnej, jak i innych subdyscyplin pedagogiki skoncentrowanych na dzieciach i młodzieży, do 
podejmowania badań naukowych, analiz i refleksji odnoszących się nie tylko do wyseparowanej grupy np. uczniów z niepełnosprawnością czy sprawnych, ale rozpoznawania sytuacji edukacyjnej w odniesieniu do całej grupy uczniów. Poszukiwania uwarunkowań skutecznych rozwiązań w tym zakresie, z uwzględnieniem potrzeb całej grupy. Analogiczne działania muszą być, w moim przekonaniu, podjęte również $\mathrm{w}$ ramach podnoszonej tu problematyki starości i starzenia się.

Jak wskazuje Adam A. Zych, „tradycyjna geragogika skoncentrowana była do tej pory na człowieku normalnie starzejącym się, dopiero początek naszego stulecia wyraźnie zawraca uwagę na społeczne kwestie niepełnosprawnych osób starszych, czego wyrazem jest tworzenie geragogiki specjalnej"4. Cele geragogiki specjalnej są tożsame z celami gerentopedagogiki, ale są wyraźnie odnoszone do niepełnosprawnych osób starzejących się. . Autor wskazuje, że w ramach analiz i refleksji „tradycyjnej” pedagogiki starzenia się i starości nastawionej na zdrowe osoby starsze i starzejące się, rozwijającej swoje subdyscypliny (gerontologia edukacji, geragogika czasu wolnego, kultury i mediów, geragogika muzyczna), na marginesie rozważań pozostały zagadnienie niepełnosprawnych osób starszych ${ }^{6}$.

Starzejący się człowiek, nawet ten, który w okresie wcześniejszym nie doświadczył niepełnosprawności, z pewnością traci sprawność w zakresie wielu funkcji organizmu, jego charakterystyka w starości będzie zatem w tym okresie życia bliższa (niż w każdym poprzedzającym) osobie $\mathrm{z}$ niepełnosprawnością. Doświadczenia pedagogiki specjalnej, dorobek naukowy dyscypliny mogą dostarczyć istotnej wiedzy na temat nie tylko utrudnień w funkcjonowaniu, ale i konsekwencji tracenia czy utraty sprawności.

${ }^{4}$ A.A. Zych, Pedagogika osób z otępieniem jako nowy obszar geragogiki specjalnej, „LABOR et EDUCATIO” 2014, nr 2, s. 275.

${ }^{5}$ A.A. Zych, Geragogika specjalna - konieczność, potrzeba czy moralny obowiązek?, [w:] Pedagogika społeczna w stużbie rodziny (aspekt marginalizacyjny, resocjalizacyjny i psychologiczny, t. 2, red. K. Gąsior, T. Sakowicz, Świętokrzyskie Centrum Profilaktyki i Edukacji, Kielce 2005.

${ }^{6}$ A.A. Zych, Pedagogika osób z otępieniem... 
Zjawiskiem dobrze rozpoznanym $\mathrm{w}$ literaturze jest problematyka marginalizacji i wykluczenia osób starszych w obszarze społecznym. Zajmowało się nim wielu autorów, których obszarem zainteresowań naukowych jest osoba $w$ wieku senioralnym. Wśród obszarów wykluczenia najczęściej wskazuje się: biedę/ubóstwo, rynek usług finansowych, usług medycznych, wykluczenie cyfrowe czy aktywność kulturalną7.

W przypadku osób z niepełnosprawnością $\mathrm{w}$ wieku senioralnym zjawiska marginalizacji i wykluczenia wydają się być jeszcze poważniejsze, wynikają bowiem z nałożenia się obszarów wykluczenia będącego skutkiem niepełnosprawności i starzenia się. Brakuje jednak badań naukowych, które podejmowałyby się rozpoznania zjawiska, jego nasilenia i ich konsekwencji dla sytuacji życiowej tej grupy osób.

Dziś w krajach rozwiniętych, średnio jedna osoba na siedem (w populacji ogólnej) przekroczyła 65. rok życia. W 2030-2040 będzie nią co czwarty obywatel świata. Prognozy na rok 2030 wskazują, że najwięcej osób w wieku powyżej 65 lat zamieszkiwać będzie kraje Europy. W wieku 65 lat i więcej będzie 43,2\% ludności kontynentu ${ }^{8}$. Zgodnie z prognozami demograficznymi Eurostat, proces

${ }^{7}$ M. Kubiak, Ubóstwo czy wykluczenie ludzi starszych, [w:] Oblicza biedy we wspótczesnej Polsce, red. M. Popow, P. Kowzan, M. Zielińska, M. Prusinowska, M. Chruściel, Wydawnictwo UG, Gdańsk 2011; B. Szatur-Jaworska, Ludzie starzy i starość w polityce społecznej, Wydawnictwo ASPRA-JR, Warszawa 2000; E. Trafiałek, Polska starość w dobie przemian, Wydawnictwo Naukowe „Śląsk”, Katowice 2003; P. Kubicki, Osoby starsze na rynku ustug finansowych. Analizy i zalecenia, BRPO Warszawa 2013; P. Kubicki, Ubóstwo i wykluczenie społeczne osób starszych, www.eapn.org.pl/wp-content/up loads/.../Ubostwo-i-wykluczenie-osołb-starszych.pdf [dostęp: 24.08.2017], J. Derejczyk, Geriatria, a reforma ochrony zdrowia w Polsce, "Służba Zdrowia” 2001, nr 61-64; B. Szmigielska, A. Bąk, M. Hołda, Seniorzy jako użytkownicy Internetu, "Nauka” 2/2012; L. Frąckiewicz, Wykluczenie i spójność społeczna wobec procesu starzenia się ludności, [w:] Zostawić ślad na ziemi, red. M. Halicka, J. Halicki, Wydawnictwo Uniwersytetu w Białymstoku, Białystok 2006.

8 Jednym z najstarszych demograficznie krajów świata stają się Włochy. W 2000 r. ponad 18\% Włochów osiągnęło wiek 65 lat i więcej, w Grecji i Szwecji - 17,3\%, Japonii $-17 \%$, Hiszpanii - 16,9\%, Belgii - 16,8\%, Niemczech - 16,2\%, Francji - 16\%, 
starzenia się ludności po roku 2035 będzie przebiegał jeszcze szybciej. W Polsce po roku 2060 mediana wieku ma przekroczyć 54 lata i będzie poza Słowacją najwyższa w UE9 .

Tabela. Prognoza udziału ludności w wieku 65+ w różnych regionach świata w 2030 r.

\begin{tabular}{|l|c|c|c|}
\hline Region świata & $65-75$ lat & $75-80$ lat & Powyżej 80 lat \\
\hline Europa & $24,3 \%$ & $11,8 \%$ & $7,1 \%$ \\
\hline Ameryka Północna & $20,3 \%$ & $9,4 \%$ & $5,4 \%$ \\
\hline Oceania & $16,3 \%$ & $7,5 \%$ & $4,4 \%$ \\
\hline Azja & $12,0 \%$ & $4,6 \%$ & $2,2 \%$ \\
\hline Ameryka Łacińska & $11,6 \%$ & $4,6 \%$ & $2,4 \%$ \\
\hline $\begin{array}{l}\text { Bliski Wschód i Afryka } \\
\text { Północna }\end{array}$ & $8,1 \%$ & $2,8 \%$ & $1,3 \%$ \\
\hline Afryka Subsaharyjska & $3,7 \%$ & $1,3 \%$ & $0,6 \%$ \\
\hline
\end{tabular}

Źródło: opracowanie własne na podstawie K. Kinsella, V.A. Velkoff, The Demographics of Aging, „Aging Clin. Exp. Res” 2001, 14, s. 160 za: Z. Szweda-Lewandowska, Starzenie się i starość - ogólna charakterystyka, [w:] P. Błędowski, B. Szatur-Jaworska, Z. Szweda-Lewandowska, P. Kubicki, Raport na temat sytuacji osób starszych w Polsce, IPiSS, Warszawa 2012, s. 20

Ze wzrostem populacji ludzi $\mathrm{w}$ podeszłym wieku rosnąć będą wydatki państwa związane m.in. z opieką społeczną i zdrowotną. Starszy wiek nie musi być jednak synonimem złego stanu zdrowia i niepełnosprawności. Istotną rolę odgrywają tu czynniki socjokulturowe. Do najważniejszych zaliczyć trzeba m.in. płeć, status społeczny czy doświadczenia kulturowe ${ }^{10}$. Zespół badaczy pod kierun-

Z. Szweda-Lewandowska, [w:] Raport na temat sytuacji osób starszych w Polsce, P. Błędowski, B. Szatur-Jaworska, Z. Szweda-Lewandowska, P. Kubicki, IPiSS, Warszawa 2012, s. 21.

${ }^{9}$ P. Błędowski, Konsekwencje procesu demograficznego starzenia się ludności jako zadanie dla administracji publicznej, [w:] Raport na temat sytuacji osób starszych..., s. 39.

${ }^{10}$ Program Operacyjny Kapitał Ludzki, Narodowe Strategiczne Ramy Odniesienia 2007-2013, Ministerstwo Rozwoju Regionalnego, Warszawa, 2007, za: I. Chrzanowska, Starość z niepetnosprawnościa, [w:] Cztowiek i jego rodzina wobec utraty zdrowia $i$ sprawności, red. A. Nowicka, J. Bąbka, Prymasowskie Wydawnictwo Gaudentinum, Lublin 2010, s. 98. 
kiem Piotra Błędowskiego wskazuje, że wśród zdiagnozowanych już, a istotnych cech procesu starzenia się polskiego społeczeństwa są m.in.: feminizacja - do roku 2030 w Polsce przewiduje się, że odsetek mężczyzn w wieku powyżej 65. roku życia wyniesie 40,7\%, a w wieku 80 lat i więcej ok. 33,5\%; singularyzacja - prognozy wskazują na możliwy, wysoki odsetek gospodarstw jednoosobowych wśród osób starszych (do 2030 r. 53,3\% gospodarstw jednoosobowych prowadzonych będzie prawdopodobnie przez osoby po 65. roku życia); regionalizacja - prognozy na 2030 r. wskazują, że największy odsetek osób w wieku 75+ zamieszkiwał będzie tereny województwa łódzkiego - 12,6\%, dolnośląskiego i śląskiego $12,5 \%, 12,4 \%$, jedynym regionem o wskaźniku poniżej $10 \%$ będzie województwo podkarpackie $(9,9 \%)^{11}$.

Problem starzejącego się społeczeństwa staje się coraz istotniejszy dla wielu krajów (w tym głównie UE). Mimo tego, że prognozy znane są już od dawna, nie wypracowano modeli działań nastawionych na zróżnicowane potrzeby dynamicznie wzrastającej grupy osób z podeszłym wieku.

Zgodnie z przyjętą przez Polskę w 2002 r. Międzynarodową Strategią Działania w Kwestii Starzenia się Społeczeństw (Plan Madrycki) określono najważniejsze obszary działań w stosunku do ludzi starszych. Należą do nich: budowanie społeczeństwa przyjaznego ludziom w każdym wieku; ograniczenie ubóstwa wśród osób starszych (w tym idea produktywnego starzenia się, zatrudnianie starszych pracowników, edukacja osób starszych, umacnianie więzi międzypokoleniowych); dbałość o dobry stan zdrowia seniorów; zapewnienie opieki osobom niesamodzielnym; promocja solidarności międzypokoleniowej i pozytywnego wizerunku osób starszych $^{12}$. Czy i na ile wskazane tu obszary działań są priorytetowymi wobec populacji niepełnosprawnych osób starszych? Czy są to najistotniejsze działania, które należy podjąć, rozpoznając sytuację życiową niepełnosprawnych osób starszych? Na ile potrzeby nie-

\footnotetext{
11 Raport na temat sytuacji osób..., s. 5-6 i 27.

12 P. Błędowski, op. cit., s. 11.
} 
pełnosprawnych osób starszych i osób starszych, które nie doświadczyły niepełnosprawności wrodzonej czy nabytej, są analogiczne w okresie starości? To niektóre tylko pytania, które nasuwają się jako te, na które konieczne jest poszukiwanie odpowiedzi w badaniach naukowych pedagogiki specjalnej w Polsce, ale również $\mathrm{w}$ ramach studiów interdyscyplinarnych i subdyscyplinarnych $\mathrm{w}$ ramach pedagogiki.

W znacznej mierze i w większości krajów, których problem dotyczy, rozwiązania systemowe skoncentrowane są na działaniach pomocowych. Niejednokrotnie stają się one przyczyną mniej lub bardziej wyraźnych podziałów społecznych, dychotomizowania i przeciwstawiania sobie interesów grup ludzi młodych i starszych, które to wraz ze wzrostem wskaźników starzenia się społeczeństwa będą narastały. Zwłaszcza w krajach, które odpowiednio wcześnie nie zareagowały na prognozy i nie uruchomiły działań m.in. edukacyjnych skierowanych tak na kształtowanie indywidualnych wyborów, jak i społecznych relacji w tym zakresie. Nie ma wątpliwości, iż w przypadku niepełnosprawnych osób starszych niektóre przynajmniej ze wskazanych tu problemów będą bardziej nasilone. Można oczekiwać niestety, że niepełnosprawne osoby starsze okażą się szczególnie zagrożoną grupą w ramach podziałów społecznych, ze znacznie poważniejszym niebezpieczeństwem marginalizowania ich potrzeb, a tym bardziej ról społecznych.

Współczesne analizy, choćby z rodzimego obszaru, odnoszące się do populacji osób starszych (nieuwzględniające analiz separacyjnie odnoszących się do niepełnosprawnych osób starszych) wskazują jednoznacznie na grupy czynników, które warunkują poczucie satysfakcji życiowej osób starszych. Należą do nich:

- kondycja zdrowotna - generalnie nie jest $\mathrm{z}$ nią najlepiej w przypadku osób starszych. Wyniki badań wskazują, że lepszym zdrowiem cieszą się osoby bardziej wykształcone i znajdujące się w lepszej sytuacji materialnej ${ }^{13}$. Sytuacja osób z nie-

13 B. Bień, Sytuacja zdrowotna osób w podeszłym wieku, [w:] Geriatria z elementami gerontologii ogólnej, red. T. Grodzki, J. Kocemba, A. Skalska, Via Medica, Gdańsk 2006, s. 42-46. 
pełnosprawnością w wieku senioralnym w kontekście „kondycji zdrowotnej" jest znacznie gorsza. Wycinkowe analizy dotyczące niektórych tylko grup osób z niepełnosprawnością pokazują, iż np. osoby z niepełnosprawnością intelektualną często mają dodatkowe schorzenia, które wraz z wiekiem mają tendencję do pogłębiania się i nawarstwiania14. Wydaje się, że wykształcenie nie będzie w sytuacji tej grupy osób z niepełnosprawnością miało istotnego wpływu. Może go mieć natomiast sytuacja materialna. Znaczna część osób z niepełnosprawnością, nie tylko z intelektualną, utrzymuje się z rent i zasiłków pielęgnacyjnych. Jeśli niepełnosprawna osoba starsza ma jeszcze rodziców, na sytuację tę nakłada się dodatkowo konieczność podziału środków z budżetu domowego na leczenie w osoby z niepełnosprawnością i jej rodziców. Problemy materialne, niskie dochody przekładają się również na niemożność skorzystania z wszystkich możliwości rehabilitacyjno-medycznych $^{15}$. Ma to miejsce już w okresie poprzedzającym wiek podeszły i z dużym prawdopodobieństwem będzie miało swoje konsekwencje w kondycji fizycznej osób w okresie starości;

- aktywność życiowa - aktywność nadaje życiu sens, czyni je ciekawszym i bardziej wartościowym ${ }^{16}$. Jednocześnie przeciwdziała nudzie i poczuciu pustki, które mogą prowadzić do pojawiania się stanów depresyjnych. I w kontekście tego wskaźnika sytuacja osób z niepełnosprawnością w starości jawi się jako mniej korzystana. Niepełnosprawność nie musi być synonimem bierności. Istotnym uwarunkowaniem jest tu rodzaj i stopień niepełnosprawności, ale również szereg innych zmiennych: wsparcie w okresie rozwojowym i jego skuteczność, dostęp do edukacji, różnych jej form i jej efektywność,

${ }^{14}$ A. Krause, A. Żyta, S. Nosarzewska, Normalizacja środowiska społecznego osób z niepetnosprawnością intelektualna, Wydawnictwo Edukacyjne akapit, Toruń 2010, s. 95.

15 Ibidem, s. 95

${ }^{16}$ H. Zielińska-Więczkowska, K. Kędziora-Kornatowska, Determinanty satysfakcji życiowej w późnej dorosłości - w świetle doniesień badawczych, „Psychogeriatria Polska" 2010, 7(1), s. 13. 
praca, dostęp do zatrudnienie na wspólnym rynku pracy. Rozpoznanie tych, ale i innych uwarunkowań, jak i zależności między nimi wydaje się koniecznym obszarem analiz naukowych w obszarze pedagogiki specjalnej;

- poziom wykształcenia - z badań wynika, że osoby starsze z wyższym wykształceniem cieszą się lepszym samopoczuciem psychicznym. Dobry nastrój występuje czterokrotnie częściej $\mathrm{u}$ osób z wykształceniem wyższym niż z podstawo$w_{y}{ }^{17}$. Ponownie oczekiwać należy niestety, że sytuacja osób $\mathrm{z}$ niepełnosprawnością $\mathrm{w}$ wieku senioralnym będzie $\mathrm{w}$ tym zakresie większym problemem niż w populacji ogólnej, z prostej przyczyny - wskaźniki osób z wyższym wykształceniem $\mathrm{w}$ populacji osób z niepełnosprawnością są znacznie niższe niż w populacji ogólnej. Z danych BAEL z 2016 r. wynika, że wyższe wykształcenie ma 10,8\% osób niepełnosprawnych prawnie, przy 28,6\% osób sprawnych. Proporcje odwracają się w przypadku najniższych poziomów wykształcenia: gimnazjalne, podstawowe, niepełne podstawowe i bez wykształcenia, odpowiednio: $24 \%$ i $9 \%$; zasadnicze zawodowe, odpowiednio: 39,9\% i 25,3\%18. Uznając zasadność tego kryterium jako istotnego dla poczucia satysfakcji życiowej niepełnosprawnych osób starszych, uznać należy, że większa grupa osób niepełnosprawnych niż sprawnych w okresie starości wymagała będzie w tym zakresie wsparcia;

- optymizm życiowy - jak wskazują wyniki badań, najwyższy jest u osób z wyższym wykształceniem pełniących funkcje kierownicze ${ }^{19}$. Biorąc pod uwagę wcześniej przedstawione dane dotyczące np. wykształcenia osób z niepełnosprawnością,

17 J. Halik, Samopoczucie osób starszych i jego uwarunkowania, [w:] Starzy ludzie w Polsce. Społeczne skutki starzenia się społeczeństwa, red. J. Halik, ISP, Warszawa 2002, s. 71-75.

18 Dane dotyczące wykształcenia osób niepełnosprawnych na podstawie BAEL na dzień 24.03.2017, Biuro Pełnomocnika Rządu ds. Osób Niepełnosprawnych, http:/ / niepełnosprawni.gov.pl zakładka edukacja.

19 J. Halik, op. cit., s. 71-75. 
wydaje się, że wskazane przez Janusza Halika wskaźniki optymizmu życiowego osób starszych nie będą prawdopodobnie najtrafniej warunkowały optymizmu życiowego niepełnosprawnych osób starszych. Niewielki odsetek osób z niepełnosprawnością z wyższym wykształceniem i prawdopodobny jeszcze niższy osób z niepełnosprawnością pełniących funkcje kierownicze nie musi oznaczać, rzecz jasna, że niepełnosprawne osoby starsze nie przejawiają optymizmu życiowego. Warto zatem rozpoznać, co, jakie czynniki warunkują ten stan w przypadku osób z niepełnosprawnością, a w kontekście problematyki osób starszych, tę grupę osób;

- poczucie koherencji - wyniki badań wskazują, że osoby z wysokim poczuciem koherencji rzadziej przejawiają stany depresyjne, lepiej się adaptują, bardziej cieszą życiem ${ }^{20}$. W przeglądzie literatury nie znalazłam badań naukowych odnoszących się bezpośrednio do problemu poczucia koherencji osób z niepełnosprawnością $\mathrm{w}$ wieku senioralnym. W zrealizowanych przez Krystynę Kurowską i Iwonę Szumacher ${ }^{21}$ badaniach wśród niepełnosprawnych pracowników bydgoskich zakładów pracy chronionej (średnia wieku badanych nieco powyżej 46 lat, przedział wiekowy badanych 24-67 lat) ustalono, iż rodzaj schorzenia nie jest czynnikiem determinujących poziom poczucia koherencji. Jak jednak podkreślają same autorki, badania zrealizowano w niewielkiej grupie badawczej (69 osób) i to osób pracujących, ich status społeczno-ekonomiczny był zatem wyższy od niepełnosprawnych pozostających na utrzymaniu rodziny22. Poczucie koherencji uznawane jest jako

${ }^{20}$ L. Zając, Psychologiczna sytuacja człowieka starszego oraz jej determinanty, [w:] Starość i osobowość, red. K. Obuchowski, AB, Bydgoszcz 2002, s. 53-112; A. Antonovsky, Rozwikłanie tajemnicy zdrowia. Jak radzić sobie ze stresem $i$ nie zachorować, IPN, Warszawa 2005.

${ }^{21}$ K. Kurowska, I. Szumacher, Poczucie koherencji a otrzymywane wsparcie wśród niepetnosprawnych pracowników zatrudnionych w zakładach pracy chronionej, „Problemy Pielęgniarstwa" 2011, 19(1).

22 Ibidem, s. 97. 
istotna determinanta satysfakcji życiowej23. Satysfakcja życiowa z kolei łączy się z poczuciem jakości życia, a jednym z ważniejszych jej (jakości życia) determinantów jest zdrowie ${ }^{24}$. Przyjmując, że stan zdrowia niepełnosprawnych osób $\mathrm{w}$ wieku senioralnym jest gorszy niż $\mathrm{w}$ analogicznej grupie w populacji ogólnej, należałoby oczekiwać, iż poziom poczucia koherencji niepełnosprawnych osób starszych będzie niski, przynajmniej niższy niż $\mathrm{w}$ populacji ogólnej. Czy tak jest $\mathrm{w}$ istocie? Trudno stwierdzić, pogłębionych badań z tego zakresu w dorobku polskiej pedagogiki specjalnej brakuje. $\mathrm{Na}$ specyfikę problematyki $\mathrm{w}$ odniesieniu do osób $\mathrm{z}$ niepełnosprawnością wskazują pośrednio analizy i refleksje Stanisława Kowalika. Co prawda w odniesieniu do wcześniejszego okresu życia - dorosłości - autor pisze, iż w przypadku osób z niepełnosprawnością nabytą dochodzić może do redukcji dorosłości, nagłego przejścia do stanu, który przypomina starość, zmian, które przypominają sytuację utraty sprawności w starości, których odwrócić nie można 25 ;

- rodzina - zwłaszcza relacje z dorosłymi dziećmi mają istotne znaczenie dla poczucia satysfakcji życiowej (tym wyższe im wyższy jest poziom poczucia szczęścia i osiągnięć dziecka). Istotne znaczenie ma również poczucie bliskości z rodziną ${ }^{26}$. Adam A. Zych ${ }^{27}$ w kontekście osób starzejących się i starych wspomina o przemocy w postaci zaniedbania, dyskryminacji

${ }^{23}$ H. Zielińska-Więczkowska, W. Ciemnoczołowski, T. Kornatowski i wsp., Poczucie koherencji a satysfakcja życiowa stuchaczy Uniwersytetu Trzeciego Wieku, „Gerontologia Polska" 2011, 19(2).

24 B. Woynarska, Edukacja zdrowotna, PWN, Warszawa 2007.

25 S. Kowalik, Dorostość osób niepetnosprawnych w świetle koncepcji utraconego rozwoju, [w:] Dorostość, niepetnosprawność, czas współczesny. Na pograniczach pedagogiki specjalnej, red. K. Rzeźnicka, A. Kobylańska, Oficyna Wydawnicza „Impuls”, Kraków 2003.

${ }^{26}$ M. Halicka, Rodzina - czynnik warunkujacy satysfakcję życiowa w starości, "Annales UMCS" 2004, 59, s. 289-294.

27 A.A. Zych, Geragogika specjalna... 
wiekowej i uprzedzeń. W przypadku osób z niepełnosprawnością można, w jego przekonaniu, mówić nawet o podwójnej dyskryminacji ze względu na niepełną sprawność oraz z uwagi na wiek i płeć. Ponadto panuje powszechne przekonanie, że osoby z niepełnosprawnością nie będą mogły, a przynajmniej $\mathrm{w}$ znacznym stopniu utrudnione będzie, ich realizowanie się $\mathrm{w}$ rolach aktywizujących sprawne osoby w podeszłym wieku, np. w roli dziadków opiekujących się swoimi wnukami. Ponownie jednak nie ma badan naukowych potwierdzających wiedzę potoczną. Nie można stwierdzić, której grupy osób $\mathrm{z}$ niepełnosprawnością i w jakim zakresie ograniczenia te będą dotyczyły. Jakie będą ich uwarunkowania? Wydaje się zatem, że warto podjąć wysiłek pozyskania wiedzy na ten temat.

Badania dotyczące podmiotowej grupy osób z niepełnosprawnością w wieku senioralnym uzasadnione są dodatkowo faktem, iż wskaźnik osób z niepełnosprawnością w wieku 65+ w roku 2011 (wyniki narodowego spisu powszechnego) był wyższy niż w populacji ogólnej i wynosił niemal 41\% (przy 14,7\% w populacji ogólnej). Ponad połowa $z$ tej grupy (57\%) ma prawne potwierdzenie swojej niepełnosprawności ${ }^{28}$. Warto zauważyć, że w porównaniu z rokiem 2002 o 14\% zmniejszył się udział osób starszych z prawnym orzeczeniem niepełnosprawności (z 71\% do 57\%), wzrósł z kolei i to niemal o połowę osób starszych niepełnosprawnych biologicznie, z 29\% w roku 2002 do przeszło 43\% w 2011. Szczególnie duży wzrost odnotowano wśród osób zamieszkujących tereny wiejskie (z ok. 31\% do niemal 50\%), w miastach wskaźnik wzrósł o 12\% (z ok. 28\% do 40\%). Z danych NSP 2011 wynika, że największa liczba (od 42,2\% do 47\%) osób z niepełnosprawnością w wieku 65+ zamieszkuje województwa: podlaskie, mazowieckie, lubelskie, małopolskie i opolskie. Następnie wskaźniki na poziomie 38,8-42,2\% odnotowano w województwach: łódzkim, świętokrzyskim, podkarpackim, śląskim i dolnośląskim, na poziomie 36,6-38,8\% w wo-

28 Sytuacja demograficzna osób starszych i konsekwencje starzenia się ludności Polski w świetle prognozy na lata 2014-2050, GUS, Warszawa 2014, s. 18. 
jewództwach: pomorskim i zachodniopomorskim. Najmniej osób niepełnosprawnych w wieku 65+ zamieszkuje województwa warmińsko-mazurskie, kujawsko-pomorskie, wielkopolskie, lubuskie ${ }^{29}$. Biorąc pod uwage prognozy demograficzne, należy się spodziewać, że populacja osób z niepełnosprawnością w starszym wieku (zwłaszcza z niepełnosprawnością biologiczną) będzie wzrastała, jeśli dodatkowo w takim jak wskazany za lata 2002-2011 tempie pojawi się poważny problem narastającej liczby niepełnosprawnych niezdolnych do samodzielnej egzystencji, osób wymagających profesjonalnego wsparcia w zakresie opieki, leczenia i rehabilitacji. Jest to bez wątpienia również wyzwanie dla pedagogiki specjalnej w kontekście projektowania kształcenia kadr, które będą w stanie zadania takie realizować. Wyzwanie, które powinno być niezwłocznie podjęte, ale z równoległymi działaniami konstytuującymi nową grupę zawodową asystenta starszej osoby niepełnosprawnej.

Sytuacja życiowa osób z niepełnosprawnością w starszym wieku jest, jak wskazano wcześniej, znacznie trudniejsza niż osób starszych w populacji ogólnej. Nie jest prostą sumą ograniczeń, które każda $\mathrm{z}$ tych sytuacji za sobą pociąga. Pomijając oczywiste w tym przypadku kwestie zdrowotne, dostrzec je można również w sferze socjalno-bytowej. Biorąc pod uwagę podstawowe warunki sanitarno-techniczne mieszkań, w których żyją osoby z niepełnosprawnością, można stwierdzić, że są one trudniejsze niż w pozostałych przypadkach. Tylko 45\% rodzin z osobą z niepełnosprawnością (ok. $65 \%$ w miastach i ok. $14 \%$ na wsi) ma dostęp do wodociągu, łazienki z ubikacją, c.o. i gazu (przy 52,5\% w populacji ogólnej). Status ekonomiczny większości rodzin z osobami z niepełnosprawnością jest niski ${ }^{30}$. Z danych GUS-u wynika, że 95\% osób z niepełnosprawnością utrzymuje się $\mathrm{z}$ emerytur, 28,1\% z rent $\mathrm{z}$ tytułu niezdolności do pracy, 5,5\% z rent rodzinnych, 3,7\% z rent socjalnych,

${ }^{29}$ Ibidem, s. 18-19.

${ }^{30}$ M. Zrałek, Niepetnosprawność osób starszych, [w:] Nasze starzejące się społeczeństwo. Nadzieje i zagrożenia, red. J.T. Kowaleski, P. Szukalski, Wydawnictwo UŁ, Łódź 2004, s. 101-103. 
0,8\% z zasiłku dla bezrobotnych a 0,4\% ze świadczeń i zasiłków przedemerytalnych oraz świadczeń pomocy społecznej31. Jeśli uzmysłowimy sobie dodatkowo, że starsza osoba niepełnosprawna to najprawdopodobniej ktoś o niskim wykształceniu, możliwość zmiany statusu ekonomicznego wydaje się wręcz nieprawdopodobna. Jeśli na to nałoży się utrata sił i sprawności wynikająca tak z podeszłego wieku, jak i istniejącego wcześniej zaburzenia, to znaczna część z grona osób z niepełnosprawnością jawić się będzie jako niezdolna do samodzielnego życia, bez kontroli nad nim i możliwości decydowania o czymkolwiek.

Wyniki badań realizowanych w ramach problematyki dorosłości i starości osób z niepełnosprawnością wskazują, że jednym z głównych lęków rodziców osób z niepełnosprawnością, zwłaszcza tych, których rodzaj i stopień niepełnosprawności w znacznym stopniu ograniczają im możliwość samodzielnego życia, choćby $\mathrm{z}$ niepełnosprawnością intelektualną głębszego stopnia, jest lęk przed przyszłością. Rodzice wciąż myślą o tym, z kim i gdzie ich dziecko zamieszka, gdy będzie już dorosłe, a ich zabraknie ${ }^{32}$. Istotnym w tym kontekście, a nieporuszanym problemem jest to, jak osoby $\mathrm{z}$ niepełnosprawnością poradzą sobie $\mathrm{z}$ traumą po utracie rodziców, koniecznością zamieszkania w nowym, nieznanym miejscu, wśród obcych im ludzi.

Innym problemem dobrze rozpoznanym w populacji ogólnej osób starszych ${ }^{33}$, ale nierozpoznanym w przypadku osób z niepełnosprawnością w wieku senioralnym jest zjawisko przemocy i zaniedbania. Powszechność tego zjawiska spowodowała, że na forum WHO skonstruowano definicję maltretowania i wykorzystywania osób starszych (ang. elder abuse) ${ }^{34}$. Rozumieć przez nią należy pojedyncze lub powtarzające się działania albo brak takiego działania

31 http://www.stat.gov.pl/gus/5840_14834_PLK_HTML.htm [dostęp: 31.05.2014].

32 A. Krause, A. Żyta, S. Nosarzewska, op. cit., s. 93.

33 Przemoc wobec ludzi starszych. Na przykładzie badań środowiskowych w województwie podlaskim, red. M. Halicka, J. Halicki, Wydawnictwo Temida, Białystok 2010.

${ }^{34}$ B. Mikołajczyk, Międzynarodowa ochrona praw osób starszych, Wydawnictwo Wolters Kluwer Polska, Warszawa 2012. 
(zaniechanie, np. zaniedbanie) zdarzające się w relacjach, w których należałoby oczekiwać zaufania i opieki, a które powodują krzywdę i zagrożenie dla osoby starszej ${ }^{35}$. Rozumienie pojęcia jest bardzo szerokie, oznacza nie tylko przemoc fizyczną i psychiczną wobec osób starszych, ale również wszelkie formy wykorzystywania, również pod względem finansowym. Małgorzata Halicka i Jerzy Halicki ${ }^{36}$ w zaproponowanej w oparciu o przegląd literatury typologii wskazują na różne możliwe rodzaje przemocy wobec osób starszych. Wymieniają wśród nich: przemoc fizyczną, psychiczną, finansową, seksualną, symboliczną, zaniedbanie, opuszczenie ${ }^{37}$. Przemoc symboliczna odnosi się do wymuszania zachowania wygodnego dla grup dominujących. Zaniedbanie, z kolei, to powtarzająca się deprywacja opieki, pomocy potrzebnych człowiekowi staremu w ważnych czynnościach dnia codziennego. Na świecie problemem przemocy wobec ludzi starych, jak wskazują Halicka i Halicki, zainteresowano się w latach 50. XX w., niemniej publiczne uznanie problemu przypada na lata 70 . XX w. W Europie problematyka zaczęła być poważnie traktowana od końca lat 80 . XX w., a w latach 90. XX w. zjawiskiem przemocy wobec osób starszych zajęła się WHO. Szacowane wskaźniki zjawiska (w oparciu o badania zrealizowane w pięciu krajach rozwiniętych: Kanada, Finlandia, Holandia, Wielka Brytania i Stany Zjednoczone) to 4-6\% (biorąc pod uwagę nadużycia fizyczne, psychiczne i finansowe oraz zaniedbania) ${ }^{38}$. Wskaźniki te są różne w różnych krajach. Dla przykładu, jak przytaczają Halicka i Halicki, w Korei to 6,3\%, w Izraelu 18,4\% (z przewagą nadużyć w formie zaniedbania), a w Czechach nawet $20 \%$ (różne formy przemocy wobec osób 60+)39.

W Polsce początki badań nad zagadnieniem przypadają na lata 70. XX w. Problem był wówczas sygnalizowany w kontekście innych badań np. dotyczących konfliktów międzygeneracyjnych. Pierwsze

35 Ibidem, s. 51.

36 Przemoc wobec ludzi starszych...

37 Ibidem, s. 26-27.

38 Ibidem, s. 44.

${ }^{39}$ Ibidem, s. 33. 
systematyczne badania polskie na temat ludzi starych jako przedmiotu i podmiotu patologii społecznej przypadają na lata 80-90. XX w. Potwierdziły one istnienie poczucia zagrożenia, nadużyć i zaniedbań w stosunku do ludzi w wieku senioralnym ${ }^{40}$. Przemoc wobec osób starszych to bardzo często przemoc w rodzinie, ale również we wszelkiego rodzaju instytucjach, które powołane zostały m.in. do pomocy, świadczenia usług na rzecz osób starszych. Z badań PAN realizowanych na zlecenie MPiPS w 2010 r. wynika, że 11,8\% Polaków izoluje starszych członków rodziny, 13,2\% stosuje wobec nich przemoc ekonomiczną ${ }^{41}$.

Przemoc w rodzinie skierowana jest przede wszystkim ku osobom słabym fizycznie, często niepotrafiących się bronić. Czynnikami, które mają wpływ na wzrost ryzyka cierpienia ludzi starszych, są: osłabienie poznawcze, fizyczne oraz izolacja społeczna. Z kolei kulturowe czynniki ryzyka to: postawy dyskryminacyjne (w tym przypadku wobec osób starszych), seksizm, tolerancja przemocy. Sprzyjać pojawianiu się i nasilaniu postaw przemocowych mogą: utrata tradycyjnych ról ludzi starszych, erozja rodziny i więzi społecznych, wysokie bezrobocie. Czynnikami ryzyka mogą być również charakterystyki ofiar, a wśród nich: ograniczona sprawność funkcjonalna, problemy spowodowane chorobami (np. demencją) czy izolacja społeczna osób ${ }^{42}$. Są to istotne ustalenia w kontekście zagrożenia przemocą osób z niepełnosprawnością. Związek przemocy i niepełnosprawności z rolą osoby z niepełnosprawnością jako jej ofiary jest obecny w polskiej literaturze z obszaru nauk społecz-

${ }^{40}$ Badania Halickiej z lat 90. XX w. wskazują, że ponad $20 \%$ mężczyzn w wieku 70 lat skarżyło się na brak opieki, 13\% miało poczucie izolowania od spraw rodziny, wobec $13-19 \%$ kobiet pojawiały się zaniedbania opiekuńcze, 14\% kobiet w wieku 80 lat zaniedbania dotyczyły sfery psychicznej (nieokazywanie uczuć). Ok. 12\% osób starszych wykazano nadużycia materialne, w grupie 80-latków wskaźnik wyniósł 19\% (Przemoc wobec ludzi starszych..., s. 35). Więcej na temat badan nad zjawiskiem przemocy wobec osób starszych w publikacji M. Halicka, J. Halicki, 2010.

41 Przemoc w rodzinie wobec osób starszych i niepetnosprawnych. Poradnik dla pracowników pierwszego kontaktu, red. D. Jaszczak-Kuźmińska, K. Michalska, MPiPS, Warszawa 2010, s. 12.

42 Ibidem, s. 40-42. 
nych ${ }^{43}$. Niemniej w tym przypadku w publikacjach nie były prowadzone analizy związane $\mathrm{z}$ występowaniem zjawiska $\mathrm{w}$ odniesieniu do wieku senioralnego osób z niepełnosprawnością czy poszczególnych rodzajów niepełnosprawności. Wyniki badań Krzysztofa Korzeniowskiego i Piotra Radkiewicza prowadzone w odniesieniu do zjawiska przemocy wobec osób z niepełnosprawnością z uwzględnieniem wieku kończą się na kategorii 60+ (nie ma zatem rozpoznania problematyki w odniesieniu do wieku senioralnego). Wyniki badań dla grupy 60+ wskazują, że w przypadku przemocy fizycznej, ekonomicznej i psychicznej średni wyniki, na skali od 1 - nigdy do 5 - bardzo często, wyniósł w kontekście przemocy pozarodzinnej i pierwszych trzech typów przemocy 1,6, seksualnej - 1,4. $\mathrm{W}$ odniesieniu do przemocy $\mathrm{w}$ rodzinie odpowiednio: 1,2 i 1,144.

Autorzy, analizując zjawisko przemocy wobec osób z niepełnosprawnością, koncentrują się zazwyczaj na dwóch grupach osób z niepełnosprawnością: intelektualną i fizyczną ${ }^{45}$ (trudnościach zdrowotnych: fizycznych lub psychicznych ${ }^{46}$ ). Podkreślają jednocześnie, że w Polsce brak jest wiarygodnych danych na temat zjawiska przemocy wobec osób z niepełnosprawnością ${ }^{47}$.

Monika Zima ${ }^{48}$ wskazuje, iż przemoc wobec osób z niepełnosprawnością, jak wynika z badań, może być związana np. z nieatrakcyjnym wyglądem zewnętrznym, który może powodować zaburzenia kształtowania się więzi, a pośrednio wpływać na występowanie przemocy. Szacunki wskazują również, że osoby z nie-

${ }^{43}$ K. Korzeniowski, P. Radkiewicz, Przemoc w rodzinie wobec osób starszych i niepetnosprawnych. Raport z badania ogólnopolskiego 2015 r. oraz badania porównawczego $z$ lat 2009-2015, PAN IP Warszawa 2015; Przemoc w rodzinie wobec osób starszych i niepetnosprawnych. Poradnik dla...

${ }^{44}$ K. Korzeniowski, P. Radkiewicz, op. cit., s. 75. Warto dodać, że badanymi nie były osoby z niepełnosprawnością, zrealizowano je w grupie 1000 respondentów, próbie losowo-kwotowej, reprezentatywnej dla mieszkańców polski w wieku 18 i więcej lat, s. 13.

${ }^{45}$ M. Zima, op. cit., s. 71-73.

${ }^{46}$ K. Korzeniowski, P. Radkiewicz, op. cit., s. 60.

47 J. Jaszczak-Kuźmińska, K. Michalska, op. cit., s. 82.

${ }^{48}$ M. Zima, op. cit., s. 84. 
pełnosprawnością intelektualną $\mathrm{w}$ związku $\mathrm{z}$ przemocą doznają trzykrotnie bardziej drastycznych urazów niż ma to miejsce w przypadku osób sprawnych. Prowadzone analizy związku zjawiska przemocy z niepełnosprawnością wskazują na gorszą sytuację osób $\mathrm{z}$ niepełnosprawnością $\mathrm{w}$ tym zakresie $\mathrm{w}$ porównaniu $\mathrm{z}$ osobami sprawnymi. Dotyczy to wszystkich rodzajów przemocy: ekonomicznej, psychicznej, emocjonalnej, fizycznej, seksualnej. Nierozpoznane są skutki nałożenia się na niepełnosprawność procesu starzenia, w kontekście przemocy zarówno w rodzinie, jak i instytucjonalnej, z uwagi na podeszły wiek i częstą instytucjonalną zamiast rodzinnej opiekę. Zwłaszcza iż, jak pokazują wyniki prowadzonych badań, wyższy jest odsetek oszacowań przemocy wobec osób z niepełnosprawnością poza rodziną niż w rodzinie. Zsumowane odpowiedzi przemocy częstej i bardzo częstej (obserwowanej na przestrzeni ostatnich kilku lat) dają wskaźniki procentowe w układzie: poza rodziną, w rodzinie odpowiednio dla przemocy: fizycznej 10,1\% i $5,7 \%$, ekonomicznej $12,2 \%$ i $7,4 \%$, psychicznej $13,3 \%$ i $6,3 \%$ oraz seksualnej $3,8 \%$ i $2,4 \%$. Nieco niższe są najczęściej w sytuacji, gdy badani proszeni byli o odpowiedzi dotyczące ostatniego roku (odpowiednio: przemoc fizyczna $9,1 \%$ i $5,5 \%$, ekonomiczna $10,6 \%$ i 5,8\%, psychiczna $9,7 \%$ i 5,7\%, seksualna 3,6\% i 2,4\% $)^{49}$.

W podsumowaniu warto zwrócić uwage na konieczne obszary analiz, jakie, wydaje się, że powinny zostać podjęte w ramach pedagogiki specjalnej, a które poszerzyłyby obszar rozważań zmierzających do rozpoznania zjawisk związanych z gerontologią (geragogiką) specjalną, gdyż ten obszar wydaje się być szczególnie zaniedbanym w rozważaniach pedagogiki specjalnej. Nie będzie to z pewnością zamknięta lista, gdyż odnosi się jedynie do wybranych, a poruszonych w tekście kwestii. Wydaje się zatem, że warto podjąć badania dotyczące:

- cech procesu starzenia się osób z niepełnosprawnością, choćby w odniesieniu do tych wskazanych przez Piotra Błędowskiego i współpracowników ${ }^{50}$, a obserwowanych w populacji ogólnej np.: feminizacja, singularyzacja, regionalizacja, a także poszu-

${ }^{49}$ K. Korzeniowski, P. Radkiewicz, op. cit., s. 77-78.

${ }^{50}$ Raport na temat sytuacji osób starszych... 
kiwać innych, specyficznych dla osób z niepełnosprawnością w wieku senioralnym;

- satysfakcji z życia, a w tym m.in.: kondycji zdrowotnej, aktywności życiowej, jakości życia, w tym jednego z jej istotnych wskaźników jakim jest poczucie koherencji niepełnosprawnych osób starszych w odniesieniu do np.: rodzaju niepełnosprawności, poziomu wykształcenia, sytuacji materialnej, sytuacji rodzinnej itp.;

- przemocy w rodzinie i poza nią (tzw. przemocy instytucjonalnej) wobec osób z niepełnosprawnością w wieku senioralnym, nasilenia zjawiska, jego uwarunkowań.

Nieliczne wskazane, a konieczne w moim przekonaniu, obszary badań, wynikają z autorskiego wyboru obszaru rozważań w niniejszym tekście. W rzeczywistości jednak lektura dorobku naukowego w zakresie problematyki starzenia się i starości skłania do refleksji o konieczności prowadzenia w ramach pedagogiki specjalnej badań naukowych, których celem powinno być rozpoznania sytuacji życiowej, zidentyfikowanie problemów i poznanie uwarunkowań życia osób z niepełnosprawnością w wieku senioralnym. W tym celu warto również dążyć do prowadzenia badań interdyscyplinarnych czy choćby subdyscyplinarnych w ramach pedagogiki. Niekwestionowaną wartość wydają się mieć tu również badania porównawcze populacji seniorów i osób z niepełnosprawnością w wieku senioralnym, co dałoby podstawy oczekiwania możliwości stworzenia spójnego systemu wsparcia, projektowania działań systemowych celujących w rzeczywiste zapotrzebowanie każdej z grup, a tym samym być może uniknięcia scenariusza „utraconej starości” w odniesieniu grupy osób w wieku senioralnym.

\section{Bibliografia}

Antonovsky A., Rozwikłanie tajemnicy zdrowia. Jak radzić sobie ze stresem i nie zachorować, IPN, Warszawa 2005.

Bień B., Sytuacja zdrowotna osób w podesztym wieku, [w:] Geriatria z elementami gerontologii ogólnej, red. T. Grodzki, J. Kocemba, A. Skalska, Via Medica, Gdańsk 2006. 
Błędowski P., Konsekwencje procesu demograficznego starzenia się ludności jako zadanie dla administracji publicznej [w:] P. Błędowski, B. Szatur-Jaworska, Z. SzwedaLewandowska, P. Kubicki, Raport na temat sytuacji osób starszych w Polsce, IPiSS, Warszawa 2012.

Błędowski P., Szatur-Jaworska B., Szweda-Lewandowska Z., Kubicki P., Raport na temat sytuacji osób starszych w Polsce, IPiSS, Warszawa 2012.

Brzezińska A., Społeczna psychologia rozwoju, Wydawnictwo Naukowe SCHOLAR Warszawa 2010.

Chrzanowska I., Starość z niepetnosprawnościa, [w:] Człowiek i jego rodzina wobec utraty zdrowia $i$ sprawności, red. A. Nowicka, J. Bąbka, Prymasowskie Wydawnictwo Gaudentinum, Lublin 2010.

Czerniawska O., Style życia ludzi starych, [w:] Style życia w starości, red. O. Czerniawska, Wydawnictwo WSHE, Łódź 1998.

Deklaracja Praw Osób Niepetnosprawnych (Declaration on the Rights of Disabled Persons) - 1975 r. - http://www.ohchr.org/EN/ProfessionalInterest/Pages/RightsOfDisab ledPersons.aspx [dostęp: 31.05.2014].

Deklaracja Praw Osób z Upośledzeniem Umystowym (Declaration on the Rights of Mentally Retarded Persons) - 1971 r. http://www.ohchr.org/EN/ProfessionalInterest/ Pages/RightsOfMentallyRetardedPersons.aspx [dostęp: 31.05.2014]

Derejczyk J., Geriatria, a reforma ochrony zdrowia w Polsce, "Służba Zdrowia” 2001, nr 61-64

Frąckiewicz L., Wykluczenie i spójność społeczna wobec procesu starzenia się ludności, [w:] Zostawić ślad na ziemi, red. M. Halicka, J. Halicki, Wydawnictwo Uniwersytetu w Białymstoku, Białystok 2006

Halicka M., Rodzina - czynnik warunkujący satysfakcję życiowa w starości, "Annales UMCS" 2004, 59.

Halik J., Samopoczucie osób starszych i jego uwarunkowania, [w:] Starzy ludzie w Polsce. Społeczne skutki starzenia się społeczeństwa, red. J. Halik, ISP, Warszawa 2002.

Przemoc w rodzinie wobec osób starszych i niepetnosprawnych. Poradnik dla pracowników pierwszego kontaktu, red. Jaszczak-Kuźmińska D., Michalska K., MPiPS, Warszawa 2010.

Konwencja Praw Osób Niepetnosprawnych, http://www.mpips.gov.pl/spoleczne-pra wa-czlowieka/konwencja-o-prawach-osob-niepelnosprawnych/ratyfikacja-kon wencji-o-prawach-osob-niepelnosprawnych-przez-polske/ [dostęp: 1.06.2014].

Korzeniowski K., Radkiewicz P., Przemoc w rodzinie wobec osób starszych i niepetnosprawnych. Raport z badania ogólnopolskiego 2015 r. oraz badania porównawczego $z$ lat 2009-2015, PAN IP, Warszawa 2015.

Krause A., Żyta A., Nosarzewska S., Normalizacja środowiska społecznego osób z niepetnosprawnością intelektualną, WE Akapit, Torun 2010.

Kubiak M., Ubóstwo czy wykluczenie ludzi starszych, [w:] Oblicza biedy we wspótczesnej Polsce, red. M. Popow, P. Kowzan, M. Zielińska, M. Prusinowska, M Chruściel, Wydawnictwo UG, Gdańsk 2011. 
Kubicki P., Osoby starsze na rynku ustug finansowych. Analizy i zalecenia, BRPO, Warszawa 2013.

Kubicki P., Ubóstwo i wykluczenie społeczne osób starszych, www.eapn.org.pl/wp-con tent/uploads/.../Ubostwo-i-wykluczenie-osołb-starszych.pdf [dostęp: 24.08.2017].

Kurowska K., Szumacher I., Poczucie koherencji a otrzymywane wsparcie wśród niepetnosprawnych pracowników zatrudnionych w zakładach pracy chronionej, „Problemy Pielęgniarstwa" 2011, 19(1).

Mikołajczyk B., Międzynarodowa ochrona praw osób starszych, Wydawnictwo Wolters Kluwer Polska, Warszawa 2012.

Powszechna Deklaracja Praw Człowieka, http://www.unesco.pl/fileadmin/user_upload /pdf/Powszechna_Deklaracja_Praw_Czlowika.pdf [dostęp: 12.02.2013].

Przemoc wobec ludzi starszych. Na przykładzie badań środowiskowych w województwie podlaskim, red. Halicka M., Halicki J., Wydawnictwo Temida, Białystok 2010.

Rezolucja Zgromadzenia Ogólnego ONZ 3 grudnia 1982 r. http://www.who.int/disa bilities/policies/standard_rules/en/ [dostęp: 31.05.2014].

Standardowe Zasady Wyrównywania Szans Osób Niepetnosprawnych (The Standard Rules on the Equalization of Opportunities for Persons with Disabilities http://www.un. org/documents/ga/res/48/a48r096.htm [dostęp: 31.05.2014].

Sytuacja demograficzna osób starszych i konsekwencje starzenia się ludności Polski w świetle prognozy na lata 2014-2050, GUS, Warszawa 2014.

Szatur-Jaworska B., Ludzie starzy $i$ starość w polityce społecznej, Wydawnictwo ASPRA-JR, Warszawa 2000.

Szmigielska B., Bąk A., Hołda M., Seniorzy jako użytkownicy Internetu, „Nauka” 2012, nr 2.

Światowy Program Dziatań na rzecz Osób Niepetnosprawnych (World Programme of Action Concerning Disabled Persons), ONZ 3 grudnia 1982 r. http://www.who. int/disabilities/policies/standard_rules/en/ [dostęp: 31.05.2014].

Ustawa o rehabilitacji społecznej i zawodowej osób niepetnosprawnych, 27 sierpnia $1997 \mathrm{r}$. (Dz. U. z 1997 r. Nr 123, poz. 776).

Ustawa z 19 sierpnia 1994 r., o ochronie zdrowia psychicznego, Dz. U. Nr 111, poz. 535 z późniejszymi zmianami.

Woynarska B., Edukacja zdrowotna, PWN, Warszawa 2007.

Zając L., Psychologiczna sytuacja człowieka starszego oraz jej determinanty, [w:] Starość i osobowość, red. K. Obuchowski, AB, Bydgoszcz 2002.

Zasady Ochrony Osób Cierpiacych na Choroby Psychiczne oraz Poprawy Opieki Zdrowotnej http://www.un.org/documents/ga/res/46/a46r119.htm [dostęp: 31.05.2014].

Zasady Tallinskie (Tallin Guidelines for Action on Human Resources Development in the Field of Disability), http://www.un.org/documents/ga/res/44/a44r070.htm [dostęp: 31.05.2014].

Zielińska-Więczkowska H., Kędziora-Kornatowska K., Determinanty satysfakcji życiowej w późnej dorosłości - w świetle doniesień badawczych, „Psychogeriatria Polska” 2010, 7(1). 
Zielińska-Więczkowska H., Ciemnoczołowski W., Kornatowski T. i wsp., Poczucie koherencji a satysfakcja życiowa stuchaczy Uniwersytetu Trzeciego Wieku, "Gerontologia Polska" 2011, 19(2).

Zima M., Przemoc wobec osób niepetnosprawnych, [w:] Przemoc w rodzinie wobec osób starszych i niepetnosprawnych. Poradnik dla pracowników pierwszego kontaktu, red. D. Jaszczak-Kuźmińska, K. Michalska, MPiPS, Warszawa 2010.

Zrałek M., Niepetnosprawność osób starszych, [w:] Nasze starzejące się spoteczeństwo. Nadzieje i zagrożenia, red. J. T. Kowaleski, P. Szukalski, Wydawnictwo UŁ, Łódź 2004.

Zych A.A., Geragogika specjalna - konieczność, potrzeba czy moralny obowiazzek?, w: Pedagogika społeczna w stużbie rodziny (aspekt marginalizacyjny, resocjalizacyjny i psychologiczny, red. K. Gąsior, T. Sakowicz, t. 2, Świętokrzyskie Centrum Profilaktyki i Edukacji, Kielce 2005.

Zych A.A., Pedagogika osób z otępieniem jako nowy obszar geragogiki specjalnej, „LABOR et EDUCATIO" 2014, nr 2. 